\title{
Identifikasi Gosong Karang Mengggunakan Citra Satelit Sentinel 2A (Studi Kasus: Perairan Pesisir Nias Utara)
}

\author{
Identification of Coral Reef Using Sentinel 2A Satellite Imagery \\ (Case Study: Coastal Waters of Northern Nias)
}

\author{
ANANG DWI PURWANTO, TEGUH PRAYOGO, SARTONO MARPAUNG \\ Pusat Pemanfaatan Penginderaan Jauh - LAPAN \\ Jl. Kalisari No.8, Pekayon, Pasar Rebo, Jakarta 13710 \\ Email : anang.dwi@lapan.go.id / anang_depe@yahoo.com
}

\begin{abstract}
The waters of Northern Nias, North Sumatra Province have a great potential for natural resources, one of which is the reef which is often used as a fishing ground. This study aims to identify and monitor the distribution of coral reefs around the waters of Northern Nias. The location of study is limited by coordinates $97^{\circ} 0^{\prime} 31^{\prime \prime}-97^{\circ} 16^{\prime} 54^{\prime \prime} E$ and $1^{\circ} 29^{\prime} 2^{\prime \prime} L U-1^{\circ} 6^{\prime} 24^{\prime \prime} N$. The study locations were grouped in 6 (six) areas including Mardika reef, Wunga reef, Mausi1 reef, Mausi2 reef, Tureloto reef and Senau reef. The data used were Sentinel 2A imagery acquisition on 19 September 2018 and field observations made on 6-12 September 2018. Data processing includes geometric correction, radiometric correction, water column correction and classification using pixel-based and object-based methods as well as by delineating on the image. One classification method will be chosen that is most suitable for the location of the reef. The results show Sentinel $2 A$ was very helpful in mapping the distribution of coral reefs compared to direct observation in the field. The use of image classification method rightly is very helpful in distinguishing coral reef objects from surrounding objects. The estimated area of coral reefs was 1,793.20 ha with details of the Mardika reef 143.27 ha, Wunga reef 627.06 ha, Mausi1 reef 299.84 ha, Mausi2 reef 141.873 ha, Tureloto reef 244.73 ha, Senau reef 336.44 ha. The existence of coral reefs have a high potential as a fishing ground and a natural tourist attraction.
\end{abstract}

Keywords: coral reefs, sentinel 2A, lyzenga 1978, image classification, Northern Nias

\begin{abstract}
ABSTRAK
Perairan Nias Utara yang terletak di Provinsi Sumatra Utara memiliki potensi kekayaan alam yang besar dimana salah satunya adalah gosong karang yang sering dijadikan lokasi penangkapan ikan oleh nelayan. Penelitian ini bertujuan untuk mengidentifikasi dan monitoring sebaran gosong karang di sekitar

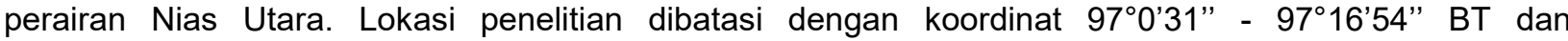

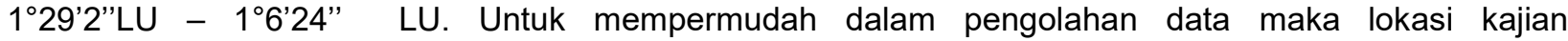
dikelompokkan dalam 6 (enam) kawasan diantaranya gosong Mardika, gosong Wunga, gosong Mausi1, gosong Mausi2, gosong Tureloto dan gosong Senau. Data yang digunakan adalah citra satelit Sentinel 2A hasil perekaman tanggal 19 September 2018 dan hasil pengamatan lapangan yang telah dilakukan pada tanggal 6 - 12 September 2018. Pengolahan data meliputi koreksi geometrik, koreksi radiometrik, koreksi kolom air dan klasifikasi menggunakan metode klasifikasi berbasis piksel dan berbasis objek serta deliniasi citra. Dari ketiga metode klasifikasi tersebut akan dipilih satu metode klasifikasi yang sesuai dengan lokasi gosong karang. Hasil penelitian menunjukkan citra Sentinel 2A sangat membantu dalam memetakan sebaran gosong karang dibandingkan dengan pengamatan langsung di lapangan. Pemilihan metode klasifikasi citra satelit yang tepat sangat membantu dalam membedakan objek gosong karang dengan objek di sekitarnya. Estimasi total luasan gosong karang di perairan Nias Utara adalah 1,793.20 ha dengan rincian luasan gosong karang Mardika 143.27 ha, gosong Wunga 627.06 ha, gosong Mausi1 299.84 ha, gosong Mausi2 141.873 ha, gosong Tureloto 244.73 ha, gosong Senau 336.44 ha. Keberadaan gosong karang memiliki potensi yang tinggi sebagai lokasi penangkapan ikan dan memiliki daya tarik sebagai tempat wisata alam.
\end{abstract}

Kata kunci: gosong karang, sentinel 2A, lyzenga 1978, klasifikasi citra, Nias Utara

\section{PENDAHULUAN}

Indonesia memiliki potensi keanekaragaman hayati pesisir yang sangat melimpah dengan panjang garis pantai lebih dari $81.000 \mathrm{~km}$ dan didukung lebih dari 17.508 pulau serta luas laut sekitar 3,1 juta $\mathrm{km}^{2(1)}$. Salah satu ekosistem pesisir yang mempunyai peranan sangat penting bagi lingkungan sekitarnya adalah 
terumbu karang. Keberadaan ekosistem terumbu karang sangat vital, menjadikannya sebagai salah satu prioritas utama dalam konservasi kehidupan maritim. Terdapat banyak definisi terkait ekosistem terumbu karang. Terumbu karang didefinisikan sebagai sebuah ekosistem komplek sebagai hasil penyusunan dari biota penghasil kapur (terutama karang) bersama biota lain yang hidup di dasar maupun kolom perairan(2). Pada sumber lainnya dijelaskan terumbu karang terbentuk dari endapan-endapan masif kalsium karbonat $\left(\mathrm{CaCO}_{3}\right)$ yang dihasilkan oleh organisme karang pembentuk terumbu (karang hermatipik) dari filum Cnidaria, ordo Scleractinia yang hidup bersimbiosis dengan zooxantellae, dan sedikit tambahan dari alga berkapur serta organisme lain yang menyekresi kalsium karbonat ${ }^{(3)}$. Beberapa fungsi dan manfaat dari ekosistem terumbu karang diantaranya: (1) sebagai pelindung alami pantai dari hempasan ombak; (2) sebagai tempat tinggal, berlindung dan pemijahan ikan dan biota laut lainnya; (3) sebagai lokasi wisata alam bawah air; (4) dapat digunakan untuk mendukung kegiatan penelitian terutama untuk identifikasi dan monitoring ${ }^{(4)}$.

Deteksi parameter biogeofisik khususnya di wilayah perairan Indonesia sangat sulit jika dilakukan dengan cara konvensional. Untuk mengatasi berbagai kendala yang ada maka perlu dilakukan dengan menggunakan teknologi penginderaan jauh dimana teknologi ini mampu mengidentifikasi suatu objek, daerah atau fenomena melalui analisis data yang diperoleh dengan suatu alat tanpa kontak langsung dengan objek, daerah, atau fenomena yang dikaji(5). Banyak keunggulan dan kelebihan yang dimiliki teknologi penginderaan jauh. Seiring perkembangan ilmu pengetahuan dan teknologi, maka teknologi penginderaan jauh juga berkembang pesat baik dari aspek resolusi (spasial, temporal, spektral dan radiometrik) beserta aplikasi pemanfaatannya. Terumbu karang sebagai salah satu penyusun ekosistem di perairan laut dangkal dimana dalam lingkup penginderaan jauh batasan istilah perairan laut dangkal merujuk pada kemampuan citra satelit dalam menembus kolom perairan ${ }^{(6)}$. Teknologi penginderaan jauh sangat efektif dan efisien dalam memetakan habitat perairan laut dangkal terutama untuk negara Indonesia yang memiliki garis pantai terpanjang kedua di dunia dan keanekaragaman habitat perairan laut dangkal ${ }^{(7)}$. Teknologi penginderaan jauh telah dimanfaatkan untuk memonitoring terumbu karang dengan mengunakan model transfer radiasi pada data Landsat- $\mathrm{TM}^{(8)}$ dan membedakan pasir karbonat, terumbu karang hidup dan makroalga menggunakan citra Landsat-ETM+(9). Hasil perbandingan estimasi terumbu karang mengunakan satelit Landsat TM dan citra dari spectrometer airborne memiliki akurasi keseluruhan $75 \%{ }^{(10)}$.

Terdapat beberapa jenis pengelompokan terumbu karang berdasarkan lokasi dan tahapan pembentukannya, salah satu adalah patch reef atau terumbu karang gosong. Terumbu karang gosong/gosong karang/karang gosong ini tumbuh dan berkembang di paparan benua atau pulau dan dalam proses tahapan pembentukannya belum mencapai permukaan laut ${ }^{(6)}$. Sebagian besar tipe terumbu karang di Indonesia adalah karang tepi dan karang gosong serta karang penghalang ${ }^{(11)}$. Parameter gosong karang terdapat di dasar perairan dan dapat dideteksi menggunakan data citra satelit penginderaan jauh. Keberadaan gosong karang memiliki peranan penting diantaranya sebagai tempat perkembangbiakan, tempat pemijahan dan tempat mencari makan berbagai jenis ikan sehingga potensial sebagai daerah penangkapan ikan oleh nelayan.

Dalam mengidentifikasi objek di bawah perairan terutama gosong karang memerlukan perlakuan khusus terkait dari pemilihan data yang digunakan sampai dengan teknik pengolahan datanya. Hal ini dikarenakan keberadaan objek gosong karang tersebut berada pada kedalaman yang bervariasi. Teori atenuasi menyatakan bahwa intensitas cahaya akan semakin berkurang seiring dengan peningkatan kedalaman perairan sehingga menyebabkan objek yang sama dalam perairan memiliki karakteristik spektral yang berbeda jika berada pada kedalaman yang berbeda(12).

Kabupaten Nias Utara merupakan salah satu wilayah di Pulau Nias, Sumatera Utara yang memiliki potensi sebaran gosong karang yang cukup tinggi(13). Salah satu ciri khas gosong karang di Pulau Nias adalah terkait keberadaannya pada kedalaman tertentu. Hal ini menjadi tantangan terutama bagi teknologi penginderaan jauh untuk dapat mengenali objek gosong karang tersebut. Salah satu citra generasi terbaru adalah citra Sentinel 2A untuk kanal Blue, Green, Red dan Near InfraRed $(\mathrm{NIR})^{(14)}$. Satelit ini diluncurkan pada tanggal 23 Juni 2015 oleh European Space Agency (ESA). Penelitian ini bertujuan untuk mengidentifikasi dan monitoring sebaran gosong karang di sekitar perairan Nias Utara menggunakan citra satelit Sentinel 2A.

\section{BAHAN DAN METODE}

\subsection{Data}

Data citra yang digunakan dalam penelitian ini adalah citra satelit Sentinel 2A hasil perekaman tanggal 19 September 2018. Pemilihan waktu 
citra berdasarkan kondisi kualitas citra yang relatif lebih baik dengan tutupan awan yang paling sedikit (terutama pada lokasi penelitian) dibandingkan periode akuisisi citra lainnya. Citra Sentinel 2A tersebut diperoleh dari European Space Agency (ESA) melalui situs Copernicus Open Access Hub (https://scihub.copernicus.eu/). Citra Sentinel 2A yang digunakan merupakan hasil perekaman sensor Multi Spectral Instrument (MSI) Level-2A dengan resolusi spasial 10 meter, yaitu kanal spektral B2 $(490 \mathrm{~nm}), \mathrm{B} 3(560 \mathrm{~nm})$, B4 $(665 \mathrm{~nm})$ dan B8 $(842 \mathrm{~nm})$.

\subsection{Metode}

\subsubsection{Lokasi Penelitian}

Lokasi penelitian berada di perairan pesisir Kabupaten Nias Utara dan sekitarnya dengan batasan koordinat $97^{\circ} 0$ '31'" - 97 $16^{\prime} 54^{\prime \prime}$ BT dan $1^{\circ} 29^{\prime}{ }^{\prime \prime}$ LU - 16'24" LU. Lokasi penelitian berada di Perairan Kabupaten Nias Utara dan sekitarnya dengan batasan koordinat seperti ditampilkan pada Gambar 1. Kabupaten Nias Utara merupakan salah satu kabupaten hasil pemekaran wilayah dari Kabupaten Nias yang berbatasan dengan Kota Gunung Sitoli di sebelah timur dan Kabupaten Nias Barat di sebelah selatan. Berdasarkan hasil pengamatan terdapat sekitar 6 (enam) gosong karang yang hampir semuanya dikelilingi oleh Samudera Hindia. Beberapa gosong karang tersebut merupakan bagian dari suatu pulau yang berpenghuni dan tidak berpenghuni atau terpisah dari pulau utama.

\subsubsection{Metode}

Pengolahan awal data secara garis besar meliputi koreksi geometrik, koreksi radiometrik, masking, koreksi kolom air dan klasifikasi. Proses geometrik menggunakan acuan titik GCP yang berasal dari citra Landsat 8 Pansharpaned untuk wilayah Nias Utara dan sekitarnya. Tujuan dari proses koreksi geometrik adalah agar data citra yang digunakan mempunyai sifat-sifat peta dalam bentuk, skala dan proyeksi(15) agar posisi koordinat citra sesuai dengan posisi bumi yang sebenarnya. Dalam koreksi geometrik dilakukan perhitungan Root Means Square Error (RMSE) menggunakan persamaan sebagai berikut ${ }^{(16)}$ :

RMSE $=\sqrt{\frac{\sum_{i=1}^{n}\left(\left(x_{i}^{\prime}-x_{i}\right)^{2}+\left(y_{i}^{\prime}-y_{i}\right)^{2}\right)}{n}}$

Keterangan:

$(\mathrm{x}, \mathrm{y}) \quad$ : Koordinat titik kontrol

$\left(x^{\prime}, y^{\prime}\right)$ : Koordinat hasil transformasi

Kriteria yang digunakan dalam penelitian ini, nilai RMSE kurang dari 1. Artinya data satelit digunakan dalam penelitian ini layak atau memenuhi batas toleransi kesalahan posisi geometrik.

Proses koreksi radiometrik meliputi kalibrasi radiometrik dan koreksi atmosfer. Kalibrasi radiometrik dilakukan untuk mendapatkan nilai pantulan Top of Atmosphere (ToA), sedangkan koreksi atmosferik dilakukan untuk mendapatkan nilai pantulan Bottom of Atmosphere (BoA) ${ }^{(17)}$.

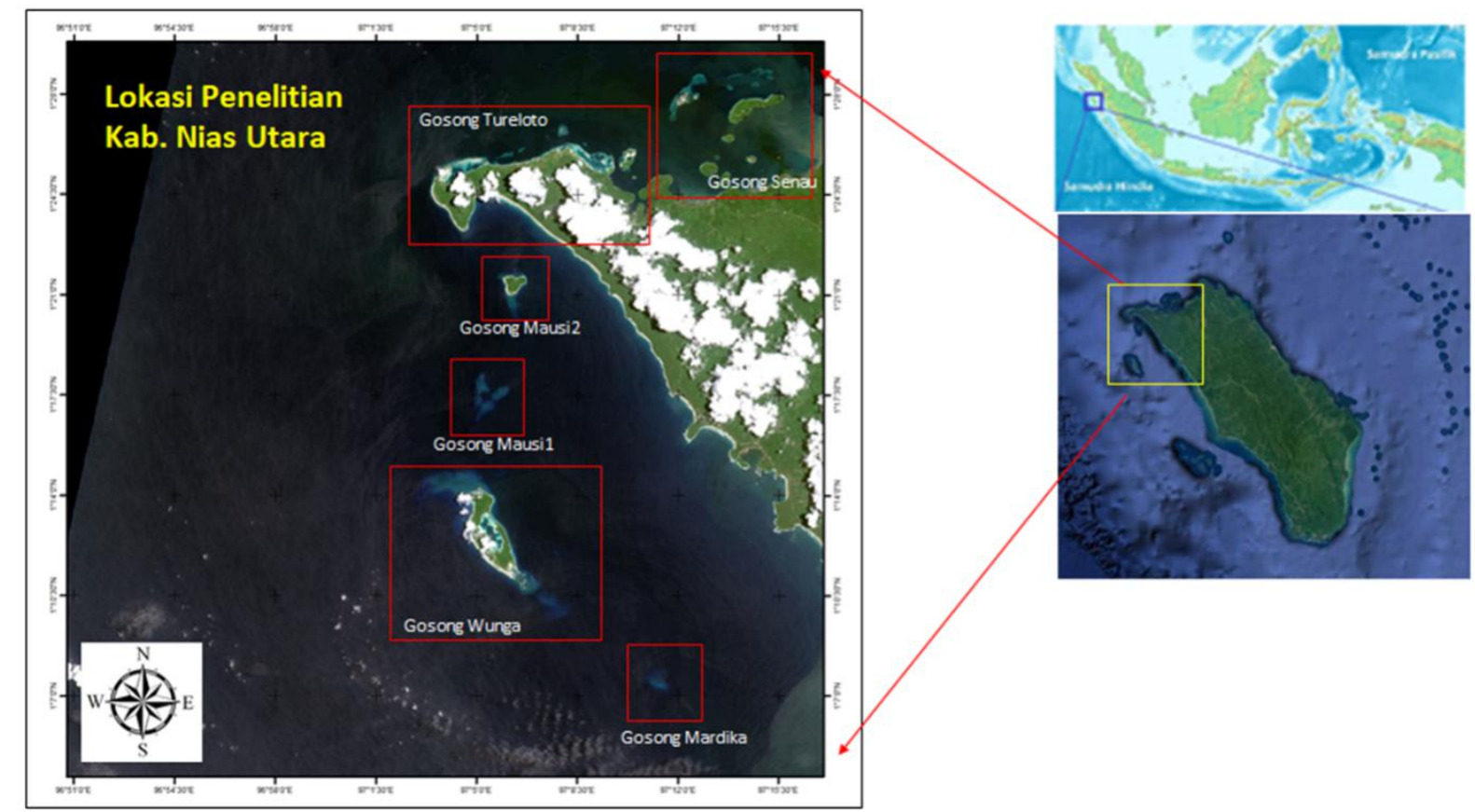

Gambar 1. Lokasi Penelitian di Perairan Nias Utara. Kotak merah merupakan lokasi gosong karang yang menjadi fokus pengamatan. (Sumber data: Citra Sentinel 2A) 
Proses koreksi radiometric dilakukan dengan menggunakan tools Semi-Automatic Classification Plugin (SCP) yang terdapat pada aplikasi Quantum GIS versi 3.6. Pada plugin ini menyediakan beberapa tools yang bisa digunakan untuk proses koreksi radiometrik beberapa citra satelit diantaranya citra Landsat, Sentinel 2 dan 3, ASTER dan MODIS. Telah dilakukan koreksi radiometrik data citra landsat menggunakan Semi Automatic Classification Plugin menggunakan piranti lunak Quantum GIS (QGIS)(18). Metode koreksi atmosfer yang digunakan adalah metode dark of substraction (DOS) dimana pada metode ini terlebih dahulu harus dibuat beberapa training area pada objek perairan relatif dalam dan bebas dari awan.

Tabel 1. Spesifikasi Band Citra Sentinel 2A(20)

\begin{tabular}{ll}
\hline Band & \multicolumn{1}{c}{$\begin{array}{c}\text { Spektrum Kanal dan Resolusi } \\
\text { Spasial }\end{array}$} \\
\hline Band1 & Coastal Aerosol, $(0.443 \mu \mathrm{m}), 60 \mathrm{~m}$ \\
\hline Band2 & Blue, $(0.490 \mu \mathrm{m}), 10 \mathrm{~m}$ \\
\hline Band3 & Green, $(0.560 \mu \mathrm{m}), 10 \mathrm{~m}$ \\
\hline Band4 & Red, $(0.665 \mu \mathrm{m}), 10 \mathrm{~m}$ \\
\hline Band5 & $\begin{array}{l}\text { Vegetation Red Edge, }(0.705 \mu \mathrm{m}), \\
20 \mathrm{~m}\end{array}$ \\
\hline Band6 & Vegetation Red Edge, $(0.740 \mu \mathrm{m})$, \\
& $20 \mathrm{~m}$ \\
\hline Band7 & Vegetation Red Edge, $(0.783 \mu \mathrm{m})$, \\
& $20 \mathrm{~m}$ \\
\hline Band8 & NIR, $(0.842), 10 \mathrm{~m}$ \\
\hline Band8A & Vegetation Red Edge, $(0.865 \mu \mathrm{m})$, \\
& $20 \mathrm{~m}$ \\
\hline Band9 & Water Vapour, $(0.945 \mu \mathrm{m}), 60 \mathrm{~m}$ \\
\hline Band10 & SWIR-Cirrus, $(1.375 \mu \mathrm{m}), 60 \mathrm{~m}$ \\
\hline Band11 & SWIR, $(1.610 \mu \mathrm{m}), 20 \mathrm{~m}$ \\
\hline Band12 & SWIR, $(2.190 \mu \mathrm{m}), 20 \mathrm{~m}$ \\
\hline
\end{tabular}

Koreksi kolom air menggunakan metode transformasi Lyzenga 1978. Proses koreksi ini bertujuan untuk menghilangkan efek dari suatu kolom air yang mempengaruhi terhadap nilai pantulan suatu objek yang diterima sensor. Koreksi kolom air dengan metode Lyzenga 1978 dilakukan dengan memperhatikan nilai dari band biru dan band hijau dari citra yang digunakan. Formulasi algoritma Lyzenga 1978 adalah sebagai indeks kedalaman invarian (Yij) dan dapat ditulis sebagai berikut:

$$
Y_{i j}=\log \left(L(\lambda)_{i}\right)-k i / k j{ }^{*} \log \left(L(\lambda)_{j}\right)
$$

Keterangan

Yij adalah indeks kedalaman invarian,

$L(\lambda)$ i mewakili nilai spektral pada band $i$

$L(\lambda)$ j mewakili nilai spektral pada band j

$\mathrm{ki} / \mathrm{kj}$ adalah koefisien atenuasi air dalam band $\mathrm{i}$ dan $\mathrm{j}$

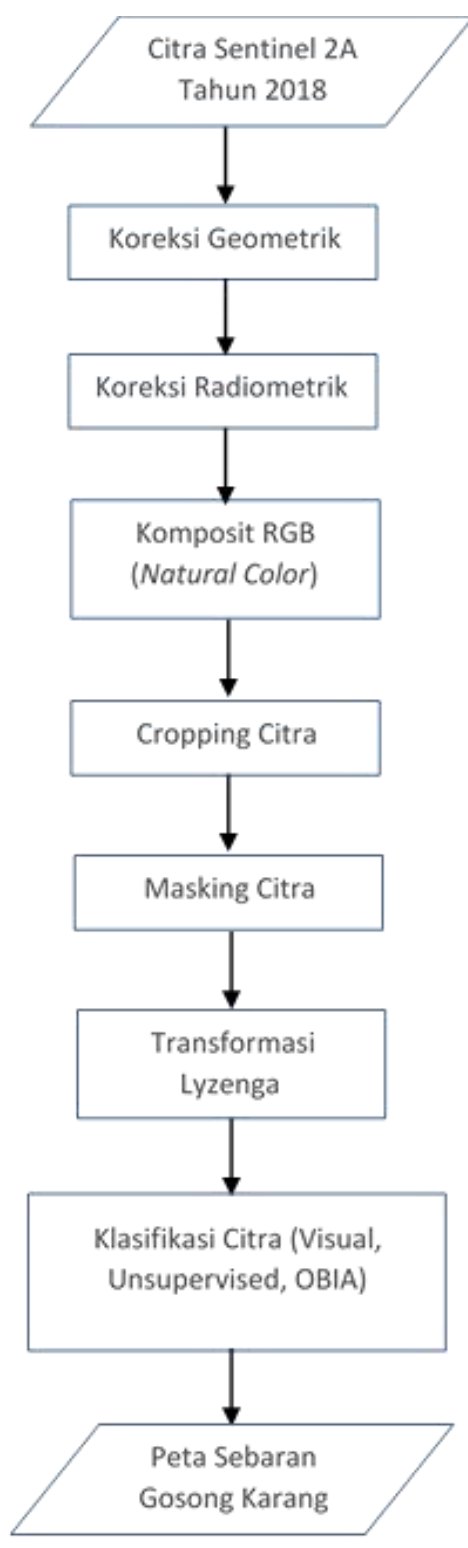

Gambar 2. Diagram Alir Penelitian

Setelah tahapan koreksi kolom air dilakukan, maka tahapan berikutnya adalah klasifikasi untuk membedakan objek gosong karang sehingga memudahkan dalam analisis lebih lanjut. Proses klasifikasi yang dilakukan menggunakan metode klasifikasi berbasis piksel (unsupervised) dan berbasis objek serta deliniasi pada citra. Dari ketiga metode klasifikasi tersebut akan dipilih satu metode klasifikasi yang sesuai dengan lokasi gosong karang. Pemilihan metode klasifikasi berdasarkan tingkat efektifitas dan efisiensi dengan mempertimbangkan beberapa faktor diantaranya kondisi kenampakannya secara visual, tingkat percampuran piksel citra (mixed pixel) dan kondisi kedalaman perairan dari masing-masing gosong karang. Proses identifikasi objek gosong karang menggunakan metode segmentasi yang terdapat pada aplikasi perangkat lunak Ecognition Developer. Metode 
segmentasi yang digunakan adalah dengan menerapkan algoritma Multiresolution Segmentation dimana metode segmentasi ini berbasis region growing yang dijalankan berdasarkan 5 (lima) parameter yaitu skala (scale), warna (colour), bentuk (shape), kehalusan (smoothness) dan kekompakan (compactness)(19). Parameter 'skala' digunakan untuk mempengaruhi jumlah segmen yang dihasilkan dimana semakin besar nilai skala semakin sedikit jumlah segmen yang terbentuk dan begitu juga sebaliknya. Parameter 'bentuk' mempengaruhi warna yang dihasilkan pada objek, sedangkan parameter 'kekompakan' mempengaruhi tingkat kehalusan dari suatu objek. Diagram alir penelitian ini ditampilkan pada Gambar 2.

\section{HASIL DAN PEMBAHASAN}

\subsection{Hasil Koreksi Geometrik}

Data citra Sentinel 2A yang telah diperoleh masih bertipe data mentah dan belum ada informasi georeferensinya sehingga diperlukan proses koreksi geometrik dengan mengambil titik ground control point (GCP) sebanyak 5-6 buah untuk masing-masing objek gosong karang. Tabel 2 menampilkan hasil perhitungan RMSE dari koreksi geometrik yang telah dilakukan. Nilai RMSE menggambarkan besarnya perbedaan antara titik uji dengan titik sebenarnya. Semakin kecil nilai RMSE berarti jarak antara titik uji dan titik sebenarnya sudah hampir sama atau bisa dikatakan memiliki tingkat ketelitian yang tinggi.

Tabel 2. Hasil Perhitungan RMSE proses koreksi geometrik

\begin{tabular}{|c|c|c|c|c|c|c|}
\hline Nama Gosong & Point & Cell-X & Cell-Y & Cell-X & Cell-Y & $\begin{array}{c}\text { RMS } \\
\text { (Piksel) }\end{array}$ \\
\hline \multirow{6}{*}{ Mardika } & 1 & 98.678 & 32.659 & 98.695 & 32.839 & 0.1802 \\
\hline & 2 & 43.459 & 73.596 & 43.538 & 73.497 & 0.1264 \\
\hline & 3 & 102.592 & 130.470 & 102.481 & 130.627 & 0.1923 \\
\hline & 4 & 141.607 & 108.466 & 141.510 & 108.116 & 0.3637 \\
\hline & 5 & 177.497 & 165.685 & 177.610 & 165.798 & 0.1599 \\
\hline & & & RMSE & & & 0.22 \\
\hline \multirow{7}{*}{ Wunga } & 1 & 551.558 & 258.596 & 551.504 & 258.565 & 0.0620 \\
\hline & 2 & 616.409 & 419.518 & 616.477 & 419.515 & 0.0674 \\
\hline & 3 & 500.515 & 418.557 & 500.538 & 418.606 & 0.0549 \\
\hline & 4 & 561.453 & 686.390 & 561.432 & 686.358 & 0.0377 \\
\hline & 5 & 747.478 & 666.539 & 747.456 & 666.559 & 0.0292 \\
\hline & 6 & 794.425 & 820.497 & 794.431 & 820.494 & 0.0061 \\
\hline & & & RMSE & & & 0.05 \\
\hline \multirow{7}{*}{ Mausi1 } & 1 & 199.448 & 89.720 & 199.449 & 89.718 & 0.0022 \\
\hline & 2 & 157.502 & 142.672 & 157.452 & 142.720 & 0.0702 \\
\hline & 3 & 156.400 & 267.680 & 156.519 & 267.570 & 0.1619 \\
\hline & 4 & 218.469 & 331.504 & 218.452 & 331.526 & 0.0279 \\
\hline & 5 & 274.570 & 259.538 & 274.442 & 259.644 & 0.1658 \\
\hline & 6 & 370.445 & 187.630 & 370.520 & 187.566 & 0.0991 \\
\hline & & & RMSE & & & 0.11 \\
\hline \multirow{7}{*}{ Mausi2 } & 1 & 46.485 & 64.624 & 46.531 & 64.577 & 0.0658 \\
\hline & 2 & 193.548 & 58.554 & 193.536 & 58.580 & 0.0290 \\
\hline & 3 & 175.661 & 125.752 & 175.665 & 125.705 & 0.0467 \\
\hline & 4 & 126.406 & 169.544 & 126.437 & 169.577 & 0.0453 \\
\hline & 5 & 92.392 & 176.544 & 92.400 & 176.499 & 0.0458 \\
\hline & 6 & 66.435 & 122.433 & 66.358 & 122.512 & 0.1103 \\
\hline & & & RMSE & & & 0.06 \\
\hline \multirow{7}{*}{ Tureloto } & 1 & 278.444 & 714.610 & 278.439 & 714.640 & 0.0306 \\
\hline & 2 & 401.373 & 248.599 & 401.333 & 248.653 & 0.0674 \\
\hline & 3 & 945.285 & 162.481 & 945.367 & 162.486 & 0.0818 \\
\hline & 4 & 1613.513 & 400.580 & 1613.460 & 400.611 & 0.0615 \\
\hline & 5 & 1172.430 & 889.538 & 1172.465 & 889.582 & 0.0569 \\
\hline & 6 & 830.500 & 532.713 & 830.482 & 532.548 & 0.1657 \\
\hline & & & RMSE & & & 0.09 \\
\hline \multirow{6}{*}{ Senau } & 1 & 153.402 & 222.458 & 153.435 & 222.494 & 0.0495 \\
\hline & 2 & 773.465 & 233.687 & 773.458 & 233.678 & 0.0118 \\
\hline & 3 & 459.423 & 513.485 & 459.361 & 513.421 & 0.0883 \\
\hline & 4 & 107.313 & 876.329 & 107.311 & 876.326 & 0.0039 \\
\hline & 5 & 781.391 & 743.365 & 781.427 & 743.405 & 0.0543 \\
\hline & & & RMSE & & & 0.05 \\
\hline
\end{tabular}


Berdasarkan Tabel 2 diperoleh total RMSE terkecil sampai dengan terbesar secara berurutan berurutan diantaranya: gosong Senau (RMSE $=0.05$ piksel), gosong Wunga (RMSE = 0.05 piksel), gosong Mausi2 (0.06 piksel), gosong Tureloto (RMSE $=0.09$ piksel), gosong Mausi1 (RMSE $=0.11$ piksel), gosong Mardika (0.22 piksel). Berdasarkan nilai RMSE terbesar yaitu 0.22 menggambarkan terjadi pergeseran geometrik sebesar 0.22 piksel $\times$ (10 meter/1 piksel) $=2.2$ meter. Hal ini menunjukkan tingkat ketelitian dari citra yang digunakan (Sentinel 2A) sudah masuk dalam batas toleransi yaitu kurang dari setengah piksel ( 5 meter). Total nilai dari keseluruhan gosong karang telah memenuhi persyaratan dari kriteria standart yang telah ditentukan (RMSE < 1) sehingga data citra layak untuk digunakan.

\subsection{Hasil Masking Objek Darat dan Laut}

Proses pemisahan darat dan laut perlu dilakukan untuk memudahkan proses pengelompokan atau klasifikasi objek gosong karang. Metode yang digunakan dengan menggunakan rasio antara band NIR dan band hijau $^{(21)}$, dengan nilai perbandingan kedua band tersebut lebih kecil dari 1,1. Nilai ambang batas (threshold) sebesar 1,1 diperoleh dari pendekatan empiris pada citra yang digunakan. Rasio perbandingan dapat dituliskan dalam formula sebagai berikut: if (input1/input2 < 1.1) THEN O ELSE 255 dimana masukan yang digunakan berasal dari band NIR untuk input1 dan band hijau untuk input2. Hasil pemisahan objek daratan dan laut ditampilkan pada Gambar 3.

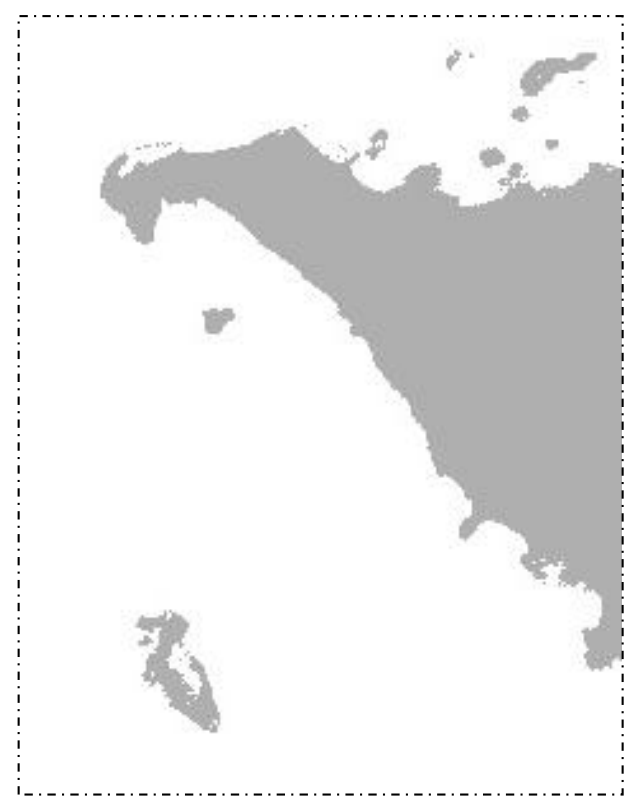

Gambar 3. Hasil Pemisahan Objek Daratan dan Laut

\subsection{Hasil Ekstraksi Gosong Karang Perairan Nias Utara}

Secara teknis ekstraksi gosong karang di peraian Nias Utara dibagi menjadi beberapa lokasi kajian diantaranya gosong Mardika, gosong Wunga, gosong Mausi1, gosong Mausi2, gosong Tureloto, gosong Senau. Hal itu dikarenakan kondisi substrat dasar dari masingmasing objek gosong karang berbeda dan ini bertujuan untuk meminimalkan pengaruh pixel campuran terutamadalam proses klasifikasi. Proses koreksi kolom air dengan metode Lyzenga 1978 sangat membantu dalam mengidentifikasi objek gosong karang yang berada pada kedalaman yang berbeda. Dalam pengambilan sampel pixel pada substrat dasar yang tidak homogen kemungkinan akan mengakibatkan nilai koefisien atenuasi $(\mathrm{ki} / \mathrm{kj})$ yang tidak rasional dan akan mempengaruhi nilai dari hasil koreksi kolom air yang dilakukan $^{(12)}$.

Pada Gambar 4a ditampilkan hasil koreksi kolom air. hasil dari koreksi kolom air menunjukkan objek gosong karang terlihat jelas dan dapat dibedakan dengan objek perairan di sekitarnya. Menurut informasi nelayan Perairan Nias Utara, lokasi keberadaan gosong karang Mardika pada kedalaman perairan sekitar 20 meter sehingga dalam proses interpretasi secara visual membutuhkan teknik penajaman lebih spesifik. Jika dilihat dari pola sebaran spasialnya pada gosong karang ini didominasi oleh substrat pasir dan di bagian tengahnya terdapat objek perairan sehingga lokasi gosong karang ini menjadi lokasi favorit para nelayan dalam menangkap ikan.

Proses klasifikasi objek gosong karang Mardika menggunakan metode klasifikasi berbasis objek. Tujuan proses segmentasi untuk memisahkan citra menjadi area-area objek yang terpisah berdasarkan parameter yang telah ditentukan sebelumnya sehingga dapat meminimalisir variabilitas antar objek (22). Pada Gambar 4b ditampilkan hasil segmentasi citra hasil koreksi kolom air menggunakan metode multiresolution segmentation. Berdasarkan penerapan metode ini secara empiris di lokasi kajian diperoleh nilai skala parameter yang optimal sebesar 30 , nilai komposisi shape sebesar 0.1 dan nilai komposisi compactness sebesar 0.5. hasil klasifikasi gosong karang Mardika ditampilkan pada Gambar 4c dimana sebaran gosong karang diperlihatkan dengan objek spasial berwarna kebiruan. 


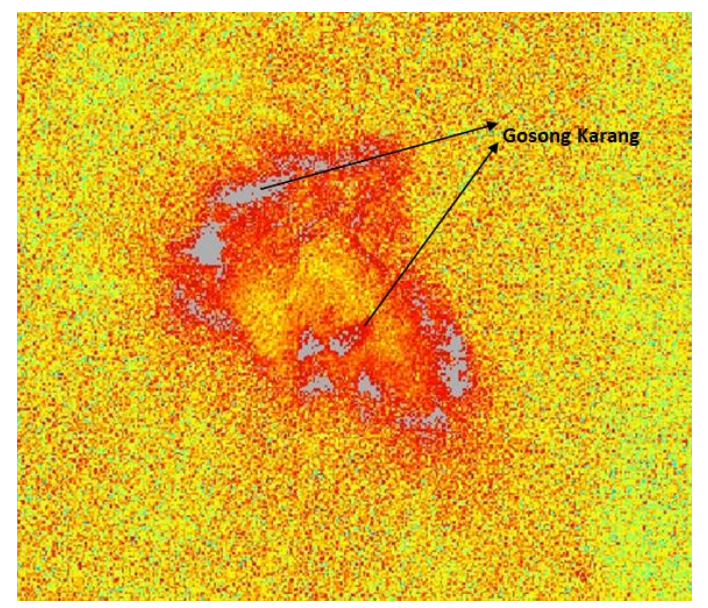

(a)

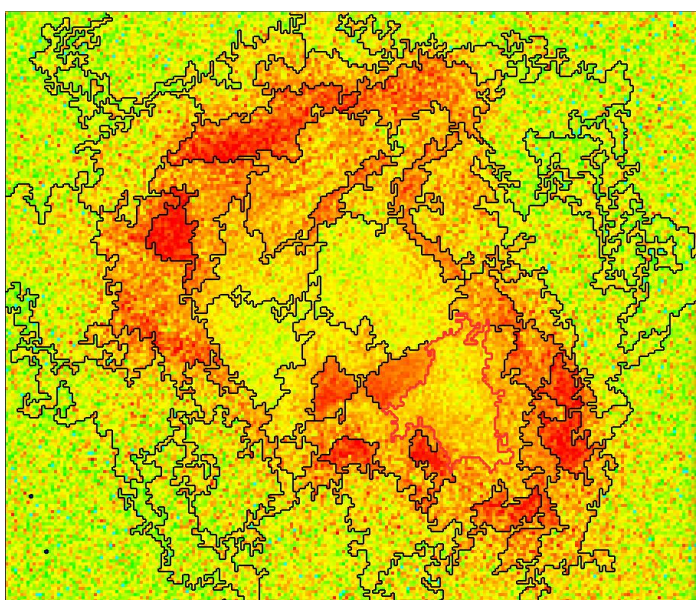

(b)

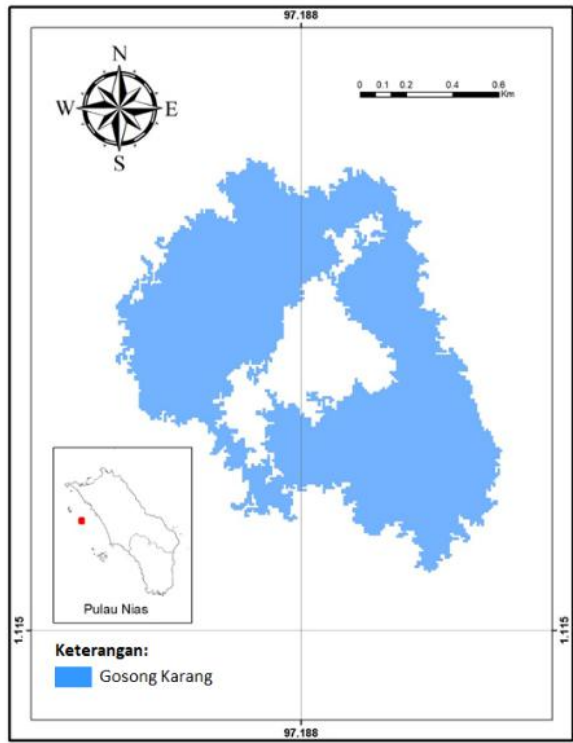

(c)

Gambar 4. (a) Hasil Koreksi Kolom Air Gosong Karang Mardika; (b) Hasil Segmentasi Citra; (c) Hasil Klasifikasi Gosong Karang Mardika(Sumber : Hasil pengolahan citra Sentinel 2A)

Gambar 5a menunjukkan hasil koreksi kolom air dari gosong karang Wunga, sedangkan untuk hasil klasifikasi ditampilkan pada Gambar 5b. Gosong Wunga ini berbeda dengan gosong karang lainnya, salah satunya yang paling terlihat jelas adalah adanya daratan pulau yang cukup luas di tengah-tengah gosong karang. Menurut Keppres RI Nomor 6 Tahun 2017 tentang penetapan pulau-pulau kecil terluar disebutkan bahwa Pulau Wunga ditetapkan sebagai salah satu pulau kecil terluar diantara 111 (seratus sebelas) pulau sebagai pulau-pulau kecil terluar. Jumlah penghuni di Pulau Wunga diperkirakan sekitar 8 kepala keluarga yang mayoritas mata pencaharian mereka adalah sebagai nelayan (http://gifarigraphy.blogspot.com/2012/04/pulauwunga-nias.html). Pulau Wunga juga mempunyai potensi yang besar sebagai tempat pengembangan budidaya rumput laut karena jika dilihat dari kenampakan citra pulau ini mempunyai areal keterlindungan yang sangat baik dengan dukungan keberadaan gosong karang di sekitarnya. Proses klasifikasi gosong karang wunga dilakukan menggunakan metode klasifikasi tak terbimbing karena kondisi tingkat percampuran pixel yang relatif rendah, kenampakan secara visual terlihat dengan jelas dan berada pada kedalaman perairan yang dangkal. Jika dilihat dari distribusi spasialnya terlihat sebaran gosong karang didominasi pada bagian utara Pulau Wunga.

Pada Gambar 6 dan Gambar 7 ditampilkan hasil koreksi kolom air dan hasil klasifikasi gosong karang Mausi1 dan Mausi2 dari citra. Kedua gosong karang tersebut diberikan penamaan Mausi karena lokasinya yang berdekatan dengan Pulau Mausi dan untuk memudahkan pengelompokan data dalam pengolahan dan analisis. Posisi gosong karang Mausi1 berada di pertengahan antara gosong karang Mausi2 dengan gosong karang Wunga. 
Perbedaan yang terlihat jelas adalah lokasi gosong karang Mausi1 berada pada kedalaman perairan yang lebih dalam dibandingkan gosong karang Mausi2. Selain itu pada gosong karang Mausi1 ini juga tidak ditemukan adanya objek daratan pulau di sekelilingnya.

Kondisi sebaran gosong karang Mausi2 tidak berbeda jauh dengan kondisi gosong karang Wunga yang di bagian tengahnya terdapat daratan pulau cukup luas yang sering dikenal dengan Pulau Mausi. Distribusi gosong karang Mausi2 terdapat di sekeliling Pulau Mausi dan sebagian besar terdapat di bagian selatan dengan bentuk menyerupai segitiga sama kaki terbalik. Proses klasifikasi gosong karang Mausi menggunakan metode deliniasi karena secara visual kondisinya dapat terlihat jelas dari citra dan berada pada kedalaman perairan yang cukup dangkal. Metode deliniasi visual terumbu karang juga telah diterapkan dengan baik pada terumbu karang tepi terkait struktur geomorfologinya dari citra foto udara $^{(23)}$.Bentuk gosong karang di kedua pulau Mausi yang cukup tegas dan kedalamananya yang dangkal serta kenampakan kolom air yang relatif jernih (tidak terdapat pengaruh kekeruhan atau sedimentasi dari sungai) memungkinkan untuk menerapkan metode ini. Berdasarkan hasil penelitian LIPI tahun 2015 bahwa perairan pulau Mausi2 sangat jernih dan kondisi relatif tenang dengan kedalaman karang sekitar 2 meter ${ }^{(24)}$.

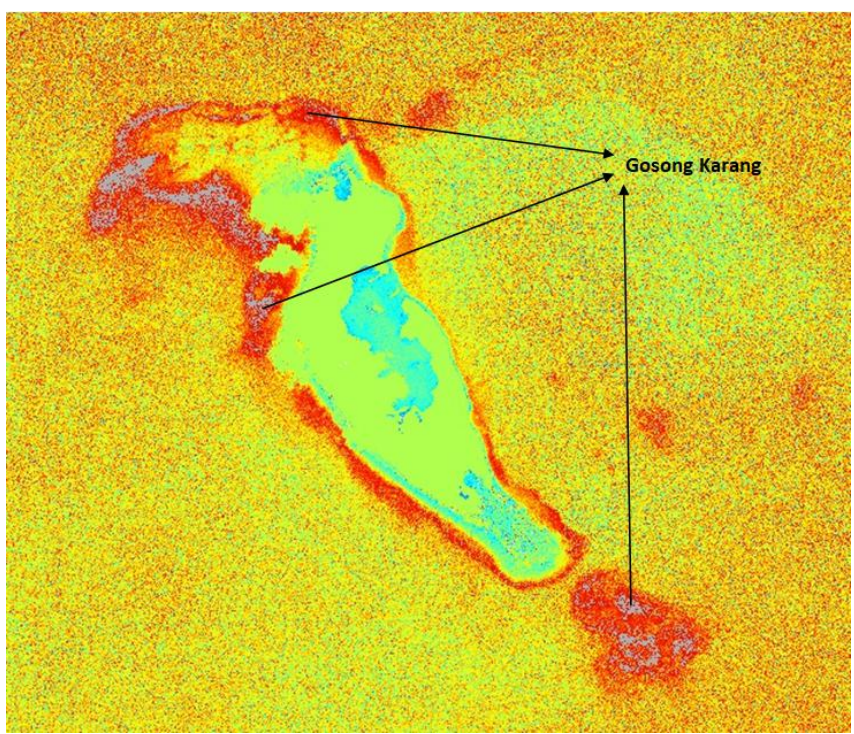

(a)

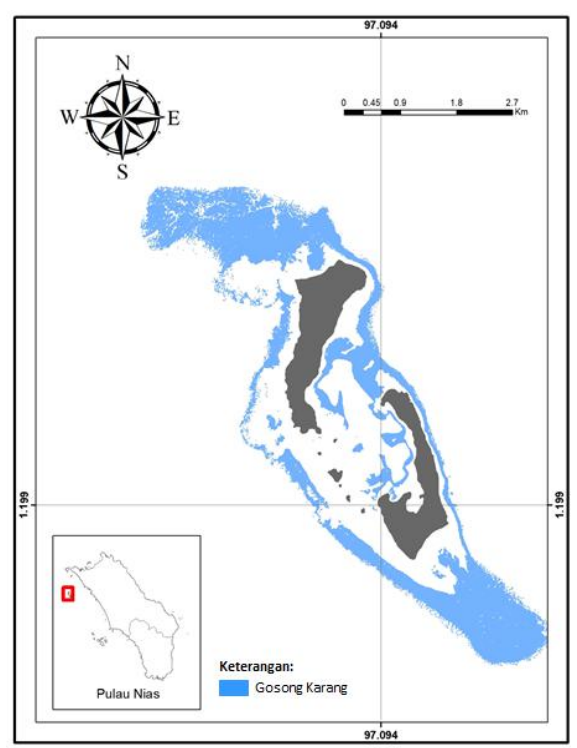

(b)

Gambar 5. (a) Hasil Koreksi Kolom Air Gosong Wunga; (b) Hasil KlasifikasiGosong KarangWunga (Sumber : Hasil pengolahan citra Sentinel 2A) 


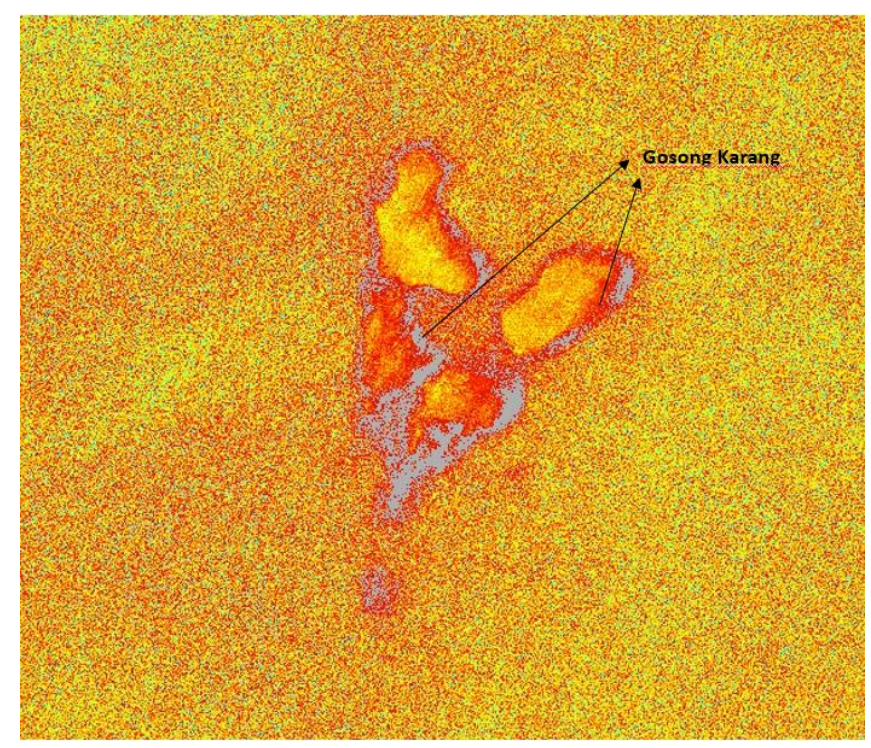

(a)

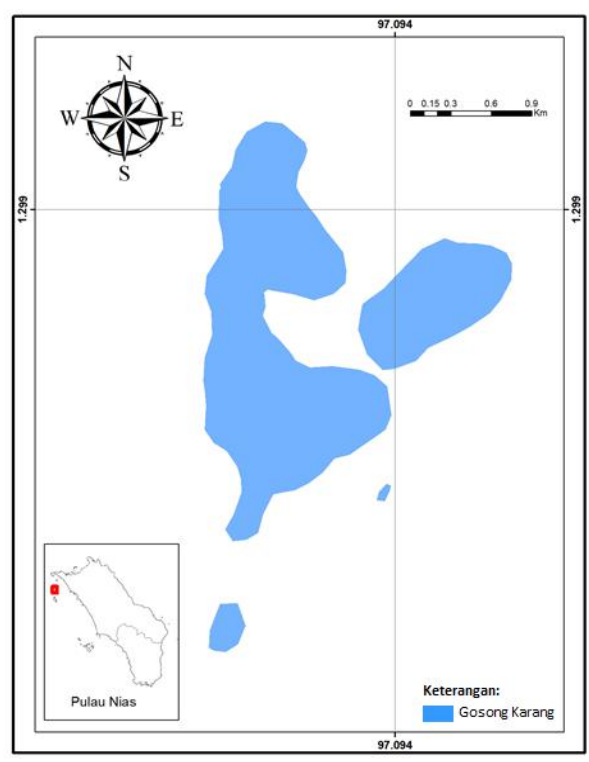

(b)

Gambar 6. (a) hasil Koreksi Kolom Air Gosong Mausi1; (b) Hasil Klasifikasi Gosong Mausi1 (Sumber : Hasil pengolahan citra Sentinel 2A)

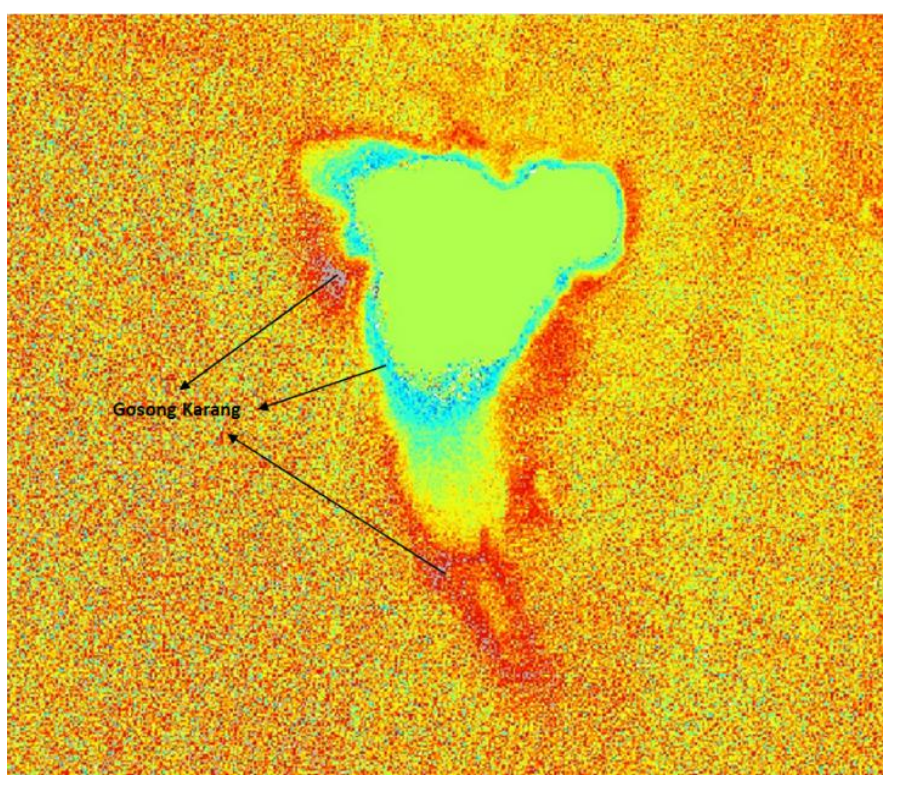

(a)

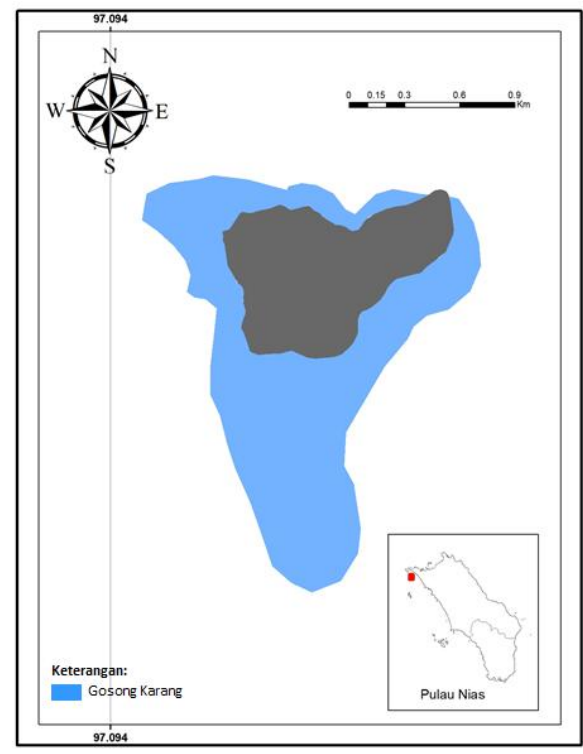

(b)

Gambar 7. (a) Hasil Koreksi Kolom Air Gosong Mausi2; (b) Hasil Klasifikasi Gosong Karang Mausi2 (Sumber : Hasil pengolahan citra Sentinel $2 \mathrm{~A}$ )

Gambar 8 dan Gambar 9 merupakan hasil koreksi kolom air dan hasil klasifikasi untuk gosong karang Tureloto dan Senau. Kedua gosong karang ini berdekatan dengan Pulau Senau dan berada pada wilayah Kecamatan Lahewa yang terletak pada bagian barat laut dari Pulau Nias. Kedua gosong karang ini memiliki jarak yang berdekatan dengan daratan Pulau Nias. Bentuk sebaran gosong karang yang cukup luas mengakibatkan pada lokasi gosong karang ini sering dijadikan sebagai lokasi penangkapan ikan bagi nelayan yang menggunakan alat tangkap pancing. Dari hasil koreksi kolom air, banyak piksel di sekitar gosong karang yang tercampur dengan piksel perairan sehingga tidak mudah untuk mengklasifikasikan objek gosong karang secara tegas menggunakan metode pixel based. Oleh karena itu pada kedua gosong karang ini dilakukan proses klasifikasi berbasis objek untuk mempermudah dalam identifikasi gosong karang. Penerapan metode identifikasi terumbu karang berbasis objek mampu menghubungkan aspek spektral dan spasial citra secara bersamaan dari hubungan antar objek, sehingga metode ini sangat baik dalam pemetaan objek perairan dangkal ${ }^{(25)}$. 


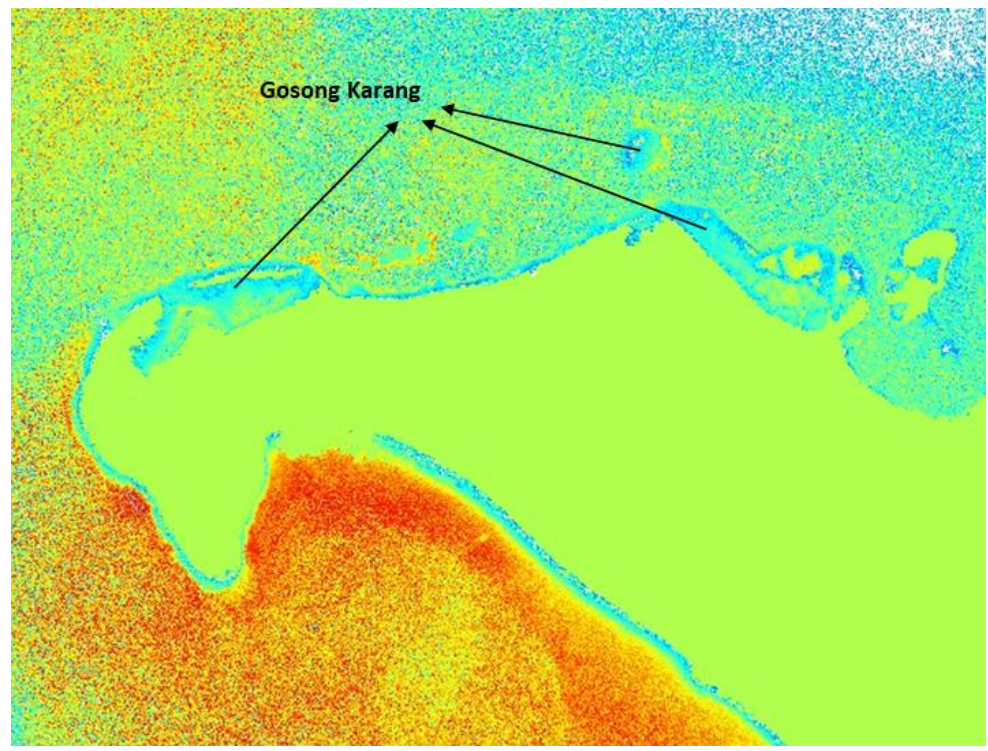

(a)

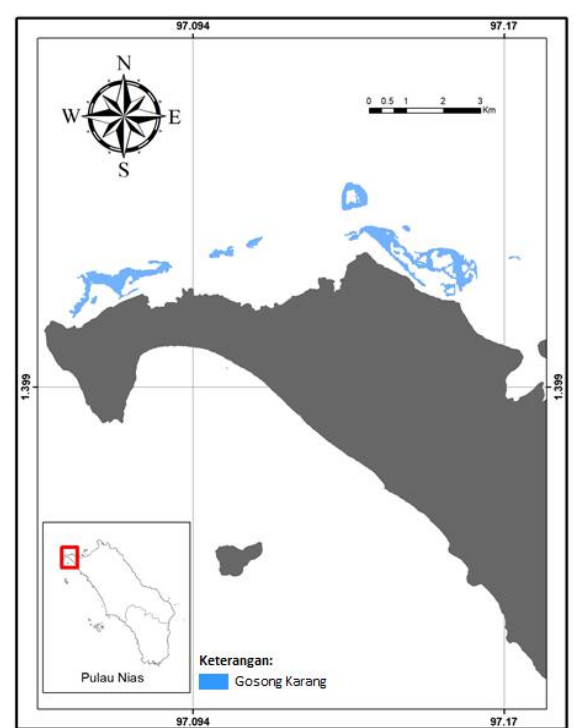

(b)

Gambar 8. (a) Hasil Koreksi Kolom Air Gosong Tureloto; (b) Hasil Klasifikasi Gosong Karang Tureloto (Sumber : Hasil pengolahan citra Sentinel 2A)

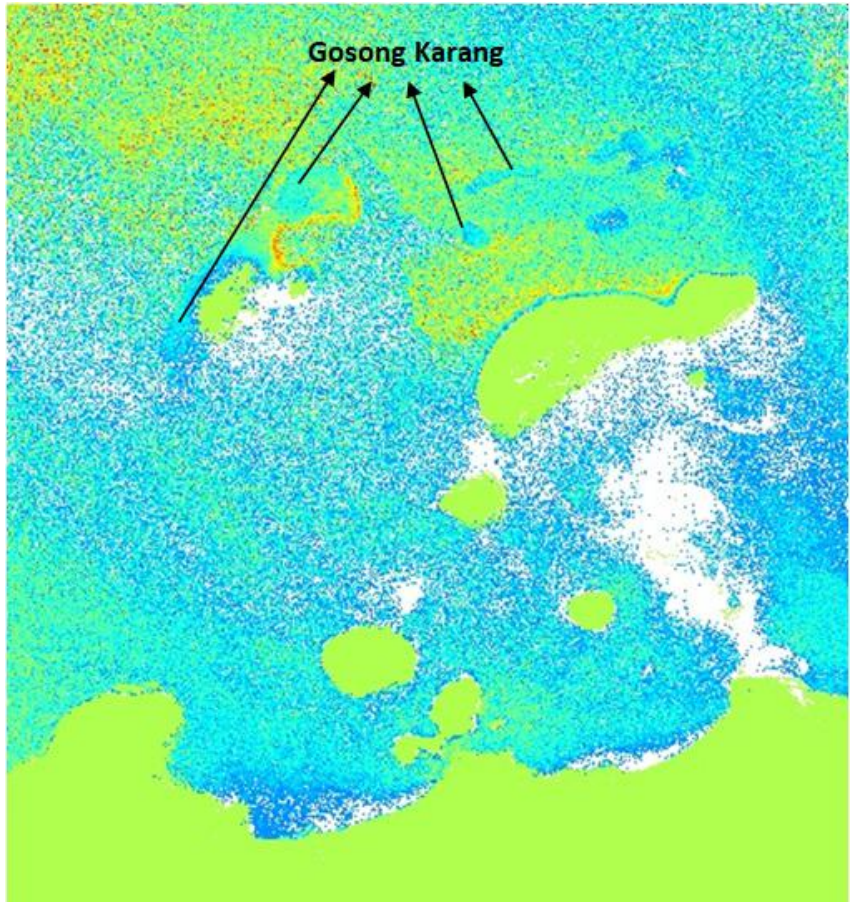

(a)

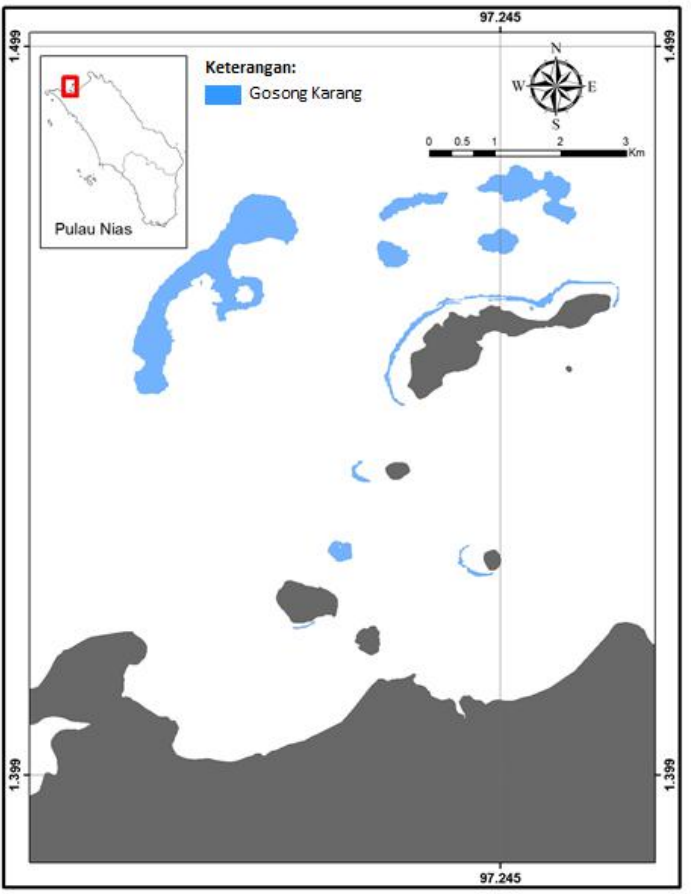

(b)

Gambar 9. (a) Hasil Koreksi Kolom Air Gosong Senau; (b) Hasil Klasifikasi GosongKarang Senau (Sumber : Hasil pengolahan citra Sentinel $2 \mathrm{~A}$ )

Berdasarkan hasil analisis visual dan hasil koreksi kolom air di setiap lokasi kajian terdapat beberapa hal yang mempengaruhi proses identifikasi gosong karang yaitu kedalaman, bentuk gosong karang, substrat dasar dan kekeruhan perairan disekitar gosong karang. Kedalaman perairan dapat menampakkan objek yang sama pada kedalaman yang berbeda atau objek yang berbeda pada kedalaman yang sama akibat proses attenuasi panjang gelombang elektromagnetik dalam kolom air(26). Area kajian dengan substrat dasar perairan pasir, pecahan karang serta transport sedimen ke perairan memiliki kondisi perairan relatif kurang jernih di sebagian tempat. Kondisi perairan cukup keruh terdapat di perairan 
sekitar Senau akibat masukan sedimen yang berasal dari keluaran air danau yang terdapat di pulau Panjang ${ }^{(27)}$. Kondisi perairan yang keruh dapat menghalangi penetrasi cahaya (akibat absorpsi dan hamburan,atau atenuasi dalam kolom air) ke dasar perairan dan mengurangi nilai reflektansi yang diterima sensor satelit. Nilai atenuasi di setiap perairan area kajian memberikan pengaruh pada tiap piksel citra khususnya piksel campuran yang dapat membiaskan identifikasi objek karang dalam air.

Secara umum area kajian yang terdapat di sekitar pantai (Wunga, Tureloto dan Senau) memiliki nilai atenuasi lebih tinggi dibandingkan di perairan lepas pantai (Mausi dan Mardika). Hal ini tidak terlepas dari karakteristik perairan lepas pantai yang tidak dipengaruhi oleh zona perairan dangkal dan sungai, sedangkan perairan pantai dipengaruhi oleh fitoplankton, padatan tersuspensi, partikel inorganik dan materi organik berwarna terlarut (colored dissolved organic matter/CDOM) $(28,29,30)$. Karakeristik perairan ini perlu menjadi pertimbangan dalam identifikasi gosong karang di perairan dangkal, meskipun kedalaman gosong karang relatif sama hasil identifikasi dapat berbeda. Berdasarkan metode identifikasi dan klasifikasi pada area kajian diperoleh luasan gosong karang yang disajikan pada Tabel 3 .

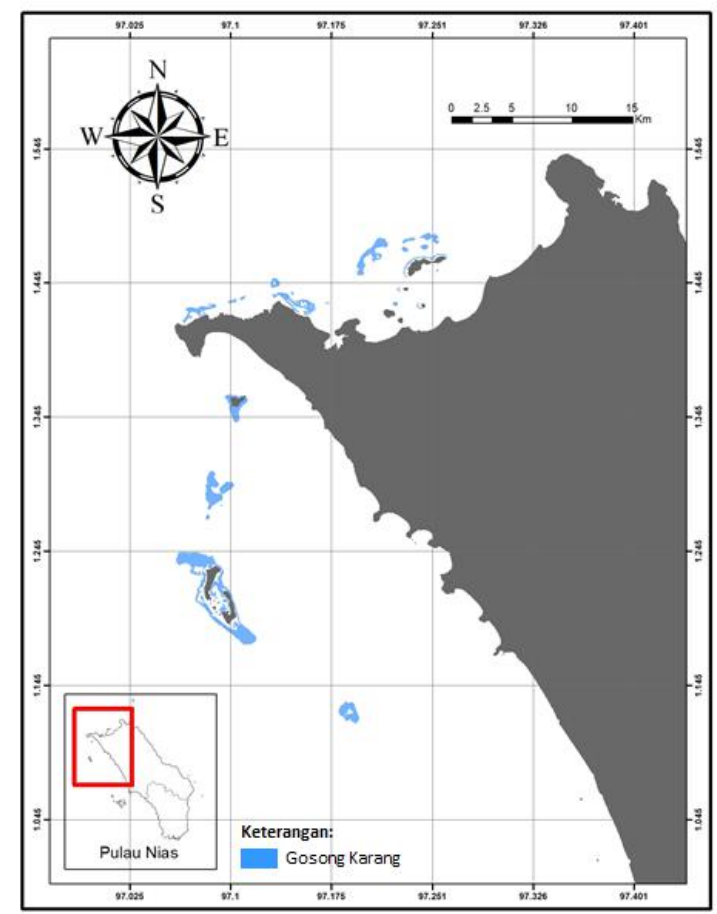

(a)
Tabel 3. Hasil Perhitungan Luasan Gosong Karang

\begin{tabular}{cll}
\hline No. & Gosong Karang & Luas (ha) \\
\hline 1 & Mardika & 143,27 \\
2 & Wunga & 627,06 \\
3 & Mausi1 & 299,84 \\
4 & Mausi2 & 141,873 \\
5 & Tureloto & 244,73 \\
6 & Senau & 336,44 \\
\hline & Total & $1.793,20$ \\
\hline
\end{tabular}

Tabel 3 menunjukkan hasil perhitungan luasan gosong karang di perairan Nias Utara dimana total luasan gosong karang di sekitar perairan Nias Utara sebesar $1.793,20$ ha. Gosong karang Wunga memiliki luasan tertinggi yaitu sebesar 627,06 ha, kemudian luasan gosong karang Mardika dan Mausi2 memiliki luasan terendah masing-masing sebesar 143,27 ha dan 141,873 ha. Kondisi gosong karang Wunga didukung dengan adanya daratan pulau yang relatif luas di bagian tengahnya yang dihuni oleh beberapa keluarga, sedangkan kondisi gosong karang Mardika berada pada kedalaman perairan yang cukup dalam, sedangkan gosong karang Mausi2 berada pada kedalaman perairan yang relatif lebih dangkal. Kedua gosong karang ini (Mardika dan Mausi2) tidak berpenghuni.

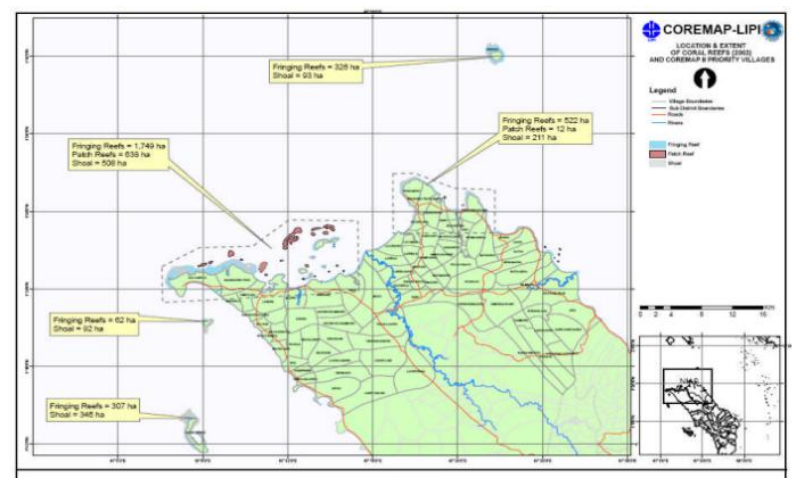

Gambar 10. (a) Sebaran Gosong Karang di Perairan Nias Utara; (b) Lokasi nelayan Nias melakukan penangkapan ikan pada area terumbu karang di perairan Nias bagian Utara (Sumber: Baseline ekologi Nias [LIPI 2007] dalam Telaumbanua [2009]) 
Hasil pemetaan sebaran gosong karang di perairan Nias Utara ditampilkan pada Gambar 10a dimana dapat terlihat kondisi sebaran gosong karang berada di sebelah utara dan barat dari perairan Nias Utara. Sedangkan Gambar 10b menunjukkan daerah penangkapan ikan nelayan Nias Utara pada area gosong karang. Hal ini menunjukkan potensi keberadaan gosong karang sebagai lokasi daerah penangkapan ikan yang potential. Berdasarkan informasi yang diperoleh dari nelayan untuk kegiatan penangkapan ikan di area gosong karang bagian utara dari perairan Nias Utara dilakukan dengan alat tangkap pancing maupun jaring hanyut (gillnet), sedangkan pada kegiatan penangkapan ikan pada area gosong karang bagian barat dari perairan Nias Utara dilakukan dengan cara menyelam. Gambaran terkait kondisi Pulau Wunga dan Pulau Mausi dari jarak lebih dekat ditampilkan pada Gambar 11 dan Gambar 12. Sedangkan dokumentasi pengamatan lapangan ditampilkan pada Gambar 13 dan Gambar 14.

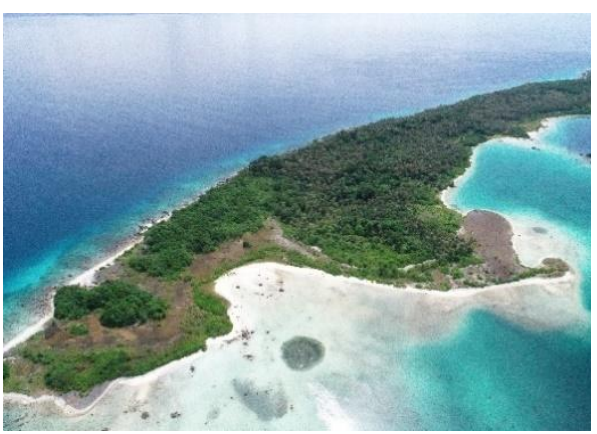

Gambar 11. Pulau Wunga dari Udara (sumber: Dokumentasi Dinas Perikanan Nias Utara)

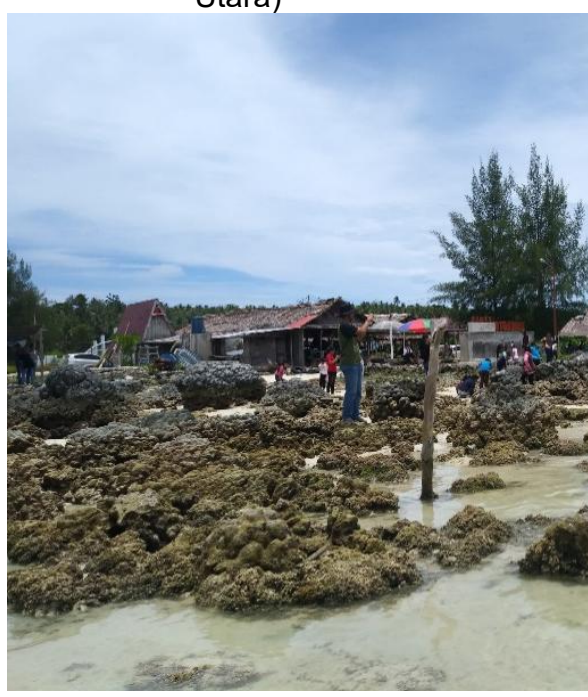

Gambar 13. Dokumentasi Survei Lapangan Nias Utara 2018 (kegiatan litbang pemanfaatan citra satelit inderaja untuk perikanan tangkap T.A 2018)

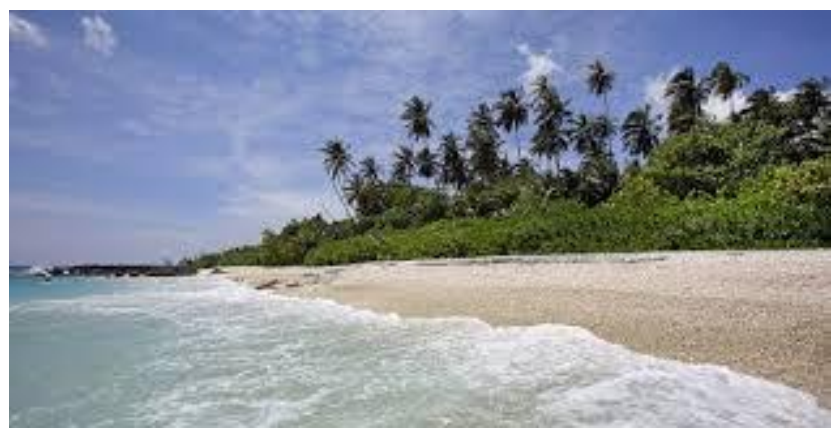

Gambar 12. Kenampakan Pulau Mausi (http://id.geoview. info/maose_island_north_nias_regency_nias_isl and,109576130p)

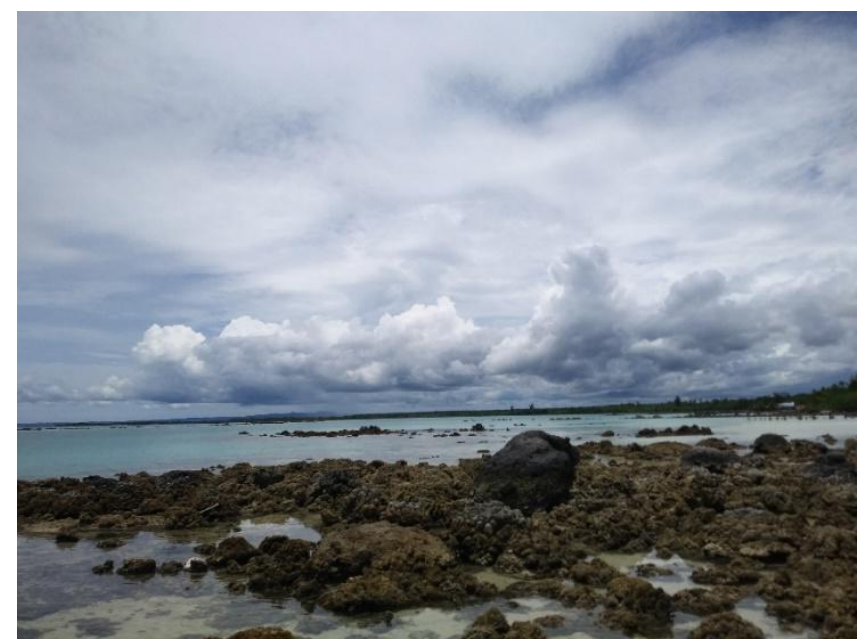

Gambar 14. Dokumentasi Survei Lapangan Nias Utara 2018 (kegiatan litbang pemanfaatan citra satelit inderaja untuk perikanan tangkap T.A 2018) 


\section{KESIMPULAN}

Hasil penelitian menunjukkan citra satelit Sentinel 2A sangat membantu dalam memetakan sebaran gosong karang dibandingkan dengan pengamatan langsung di lapangan. Pemilihan metode klasifikasi citra yang tepat sangat membantu dalam membedakan objek gosong karang dengan objek di sekitarnya. Estimasi total luasan tutupan gosong karang di perairan Nias Utara adalah 1,793.20 ha dengan rincian luasan gosong karang Mardika 143.27 ha, gosong Wunga 627.06 ha, gosong Mausi1 299.84 ha, gosong Mausi2 141.873 ha, gosong Tureloto 244.73 ha, gosong Senau 336.44 ha. Kawasan gosong karang memiliki potensi yang tinggi sebagai lokasi penangkapan ikan dan memiliki daya tarik sebagai tempat wisata alam.

\section{PERSANTUNAN}

Penulis mengucapkan terima kasih kepada Pusat Pemanfaatan Penginderaan Jauh LAPAN yang telah mendanai dan memfasilitasi kegiatan penelitian ini dan European Space Agency (ESA) yang telah menyediakan akses data citra Sentinel-2A serta Kepala Dinas Perikanan Kabupaten Nias Utara yang banyak membantu dalam kegiatan survei lapangan.

\section{DAFTAR PUSTAKA}

1. Dahuri, R., J. Rais, S.P. Ginting dan M.J. Sitepu. (1996). Pengelolaan Sumberdaya Pesisir dan Lautan Secara Terpadu. PT. Pramadya Paramita, Jakarta.

2. Hadi, T.A., Giyanto, Prayudha, B.,hafizt, M., Budiyanto, A. (2018). Status Terumbu Karang Indonesia 2018). COREMAP CTI LIPI. Jakarta. COREMAP CTI LIPI. Jakarta

3. Kambey, AD. (2014). Kondisi Terumbu Karang Pulau Bunaken Provinsi Sulawesi Utara. Jurnal Ilmiah Platax. Vol. 2:(1), Januari 2014.

4. Giyanto, Abrar, M., hadi, T.A., Budiyanto, A., hafizt, M., Salatalohy, A., Iswar, M.Y. (2017). Status Terumbu Karang Indonesia 2017. COREMAP CTI LIPI. Jakarta. COREMAP CTI LIPI. Jakarta.

5. Rahayu, L., Subiyanto, S., Yuwono, B.D. (2015). Kajian Pemanfaatan Data Penginderaan Jauh untuk Identifikasi Objek Pajak Bumi dan Bangunan(Studi Kasus : Kecamatan Tembalang Kota Semarang). Jurnal Geodesi UNDIP, Volume 4, Nomor 1, Tahun 2015.
6. Setyawan, I.E., Siregar, V.P., Pramono, G.H. Yuwono, D.M. (2014). Pemetaan Profil habitat Dasar Perairan Dangkal Berdasarkan Bentuk Topografi : Studi Kasus Pulau Panggang, Kepulauan Seribu Jakarta. Jurnal Ilmu Kelautan. 1 (1) : 126.

7. Wouthuyzen S. (2001). Pemetaan Perairan Dangkal Dengan Menggunakan Citra Satelit Landsat-5 TM Guna Dipakai Dalam Pendugaan Potensi Ikan Karang : Suatu Studi di Pulau-Pulau Padaido. Jakarta : Balitbang Sumberdaya Laut, Puslitbang Oseanologi-LIPI.

8. Lubin, D., Li, W., Dustan, P.,Stamnes, K. (2001). Spectral Signatures of Coral Reefs : Features from Space. Remote Sensing of Environment 75(1):127-137, DOI: 10.1016/S0034-4257(00)00161-9.

9. Andréfouët $S$, Muller-Karger $F$, Hochberg $E$, Hu C, Carder K (2001) Change detection in shallow coral reef environments using Landsat 7 ETM+ data. Remote Sens Environ 79:150-162.

10. P. J. Mumby P.J, E. P. Green - C. D. Clark A. J. Edwards. (1998) Digital analysis of multispectral airborne imagery of coral reefs.Coral Reefs Report (1998) 17 : 59-69.

11.Suharsono. (2008). Jenis-jenis karang di Indonesia. Program COREMAP II LIPI.Jakarta.pp 372

12. Budhiman, S., Winarso, G., \& Asriningrum, W. (2013). Pengaruh Pengambilan Training Sample Substrat Dasar Berbeda Pada Koreksi Kolom Air Menggunakan Data Penginderaan Jauh. Jurnal Penginderaan Jauh, Vol. 10 No. 2 Desember 2013 :83-92.

13. Telaumbanua, S.B. (2009). Studi Pengembangan Perikanan Tangkap Di Kabupaten Nias. Tesis. Sekolah Pascasarjana Institut Pertanian Bogor: Bogor.

14. Collin A, Laporte J, Koetz B, Martin-Lauzer F-R, Desnos Y-L. (2016). Mapping bathymetry, habitat, and potential bleaching of coral reefs using Sentinel-2. Proceedings of the 13th International Coral Reef Symposium, Honolulu: 373-387.

15. Lukiawan, R., Purwanto, E.H., \& Ayundyahrini, M. (2019). Standar Koreksi Geometrik Citra Satelit Resolusi Menengah Dan Manfaat Bagi Pengguna. Jurnal Standardisasi, Volume 21 Nomor 1, Maret 2019: hal $45-54$.

16. BIG. (2014). Pedoman Teknis Ketelitian Peta Dasar. 
17. Kristianingsih, L., Wijaya, A.P, \& Sukmono, A. (2016). Analisis Pengaruh Koreksi Atmosfer Terhadap Estimasi Kandungan Klorofil-A Menggunakan Citra Landsat 8. Jurnal Geodesi UNDIP, Volume 5, Nomor 4, Tahun 2016.

18.Sutanto, A., \& Tjahjaningsih, A. (2016). Koreksi Radiometrik Data Citra Landsat Menggunakan Semi Automatic Classification Plugin Pada Software QGIS. Prosiding Seminar Nasional Penginderaan Jauh 2016.

19. Hussein, S. (2017). Segmentasi citra algoritma Multiresolution Segmentation. Cited in https://tutorialobia.wordpress.com/2017/05/2 0/segmentasi-citra-algoritma-multiresolutionsegmentation/ [5 Juni 2019]

20.Zhang, T., Su, J., Liu, C., Hua, W.C. (2018). Potential Bands of Sentinel-2A Satellite for Classification Problems in Precision Agriculture. International Journal of Automation and Computing, DOI:10.1007/s11633-018-1143-x.

21. Setiawan, K.T., Osawa, T., Nuarsa, I.W. (2014). Aplikasi Algoritma Van Hengel Dan Spitzer Untuk Ekstraksi Informasi Batimetri Menggunakan Data Landsat. Prodising Seminar Nasional Penginderaan Jauh 2014.

22. Jhonnerie, R. (2015). Klasifikasi Mangrove Berbasis Objek Dan Piksel Menggunakan Citra Satelit Multispektral Di Sungai Kembung, Bengkalis, Provinsi Riau. Disertasi. Sekolah Pascasarjana Institut Pertanian Bogor. Bogor.

23. Lewis, J. (2002). Evidence from aerial photography of structural loss of coral reefs at Barbados, West Indies. Coral Reefs, 21(1):49-56.

24. Siringoringo R.M, Muhammad A., Ni Wayan P.S, Suyarso, Muhammad H., Kunto W., I Wayan E.D, Edi K., Hasanudin, Afdal, Ali Y.A, Triyono, Sabar J.T. (2015). Rencana Pengelolaan Dan Zonasi Taman Wisata Perairan Sawo-Lahewa Dan Laut Di Sekitarnya Sebagai Kawasan Konservasi Perairan Daerah (KKPD) Kabupaten Nias Utara. Buku Laporan LIPI dan Penelitian Dinas Kelautan dan Perikanan Nias Utara. 2015.

25. Anggoro A., Vincentius P.S, dan Syamsul B.A. (2017). Klasifikasi Multiskala untuk Pemetaan Zona Geomorfologi dan Habitat Bentik Menggunakan Metode OBIA di Pulau Pari.Jurnal Penginderaan Jauh Vol. 14 No. 2 Desember 2017 : 89-93.
26. Nurkhayati R. dan Manik H.M. (2016). GIS untuk Integrasi Interpretasi Substrat Dasar Perairan menggunakan Pengolahan citra ALOS-AVNIR dan Side-Scan SONAR. J.Oto.Ktrl.Inst (J.Auto.Ctrl.Inst) Vol 8 (1), 2016. ISSN: 2085-2517.

27. Siringoringo R.M, Suharsono, Ni WayanP.S, Yasser A., Ucu Y.A, Husni A., Wayan E.D, Oksto R.S, Kasih A. (2017). Monitoring Kesehatan Terumbu Karang dan Ekosistem Terkait Di Kabupaten Nias Utara. Buku Laporan COREMAP -CTI (Coral Reef Rehabilitation and Management Program Coral Triangle Initiative). LIPI, 2017.

28. Mobley CD. (2001). Radiative Transfer in the Ocean. Sequoia Scientific, Inc., WA, USA. Academic Press. 2321-2330.

29. Arnone R.A, Wood A.M, Gould R.W Jr. (2004). The evolution of optical water mass classification. Journal of The Oceanography Society. 17(2) : 14-15.

30. Kirk J. (2011). Light and Photosynthesis in Aquatic Ecosystems. New York. Cambridge University Press. 